\title{
Benefits of Melatonin in Health Through the Regulation of Biological Rhythms: An Update on its Therapeutic Use
}

\author{
Aline Silva de Aguiar $^{1 *}$ and Gabriela Amorim Pereira ${ }^{2}$ \\ ${ }^{1}$ Professor of the Department of Nutrition, Federal University of Juiz de Fora, Brazil \\ ${ }^{2}$ Faculty of Medicine, Federal University of Juiz de Fora, Juiz de Fora, Brazil
}

Submission: August 16, 2019; Published: September 09, 2019

*Corresponding author: Aline Silva de Aguiar, Professor of the Department of Nutrition, Federal University of Juiz de Fora, Minas Gerais, Brazil , Email: aline.aguiar@ufjf.edu.br

\begin{abstract}
Melatonin is one of the major hormones related to circadian cycle regulation in the human body. More and more studies are showing benefits of its therapeutic use, both in supplemental form and with food sources. Benefits include improvements in metabolism, antioxidant profile and sleep quality. However, there is still a need to establish the best dietary sources for this nutrient and safe supplementation doses for specific population groups.
\end{abstract}

Keywords: Melatonin; Supplementation; Food sources

\section{Introduction}

One of the main sleep-related hormones is melatonin, which regulates biological rhythms and has important antioxidant, immune and antitumor function [1,2]. In the human body melatonin can be synthesized by the pineal gland, retina, bone marrow, skin and cells of the gastrointestinal tract. Thus, being synthesized in different places, its effects do not have a specific target organ either [3]. Melatonin synthesis occurs from the neurotransmitter serotonin in the following sequence: tryptophan $\rightarrow$ serotonin $\rightarrow \mathrm{N}$-acetyl serotonin $\rightarrow$ melatonin $[1,2]$. In this sense the cells of the suprachiasmatic nucleus (SCN) receive from the retina information related to the period of the day and send to the pineal gland the command to produce melatonin. So pineal synthesizes melatonin and distributes it as a signal for its production to the body. Once released, melatonin coordinates circadian and neuroendocrine processes by activating two melatonin receptors called MT1 and MT2, coupled to $G$ protein $[4,5]$.

Secretion of this hormone begins at dusk approximately 2 hours before bedtime. Maximum plasma levels are reached between 3:00 AM and 4:00 AM, coinciding with the lowest body temperature and varying according to everyone's chronotype, seasonal changes and dark light cycle [2,3]. Once produced, melatonin is distributed to all body tissues, but is not stored.
Approximately $90 \%$ of circulating levels are metabolized in the liver and its major metabolite (6-sulfatoxymelatonin) excreted in the urine [2]. Melatonin levels decrease with age and are inversely related to poor sleep quality, so deficiency of this hormone may be responsible for decreased sleep quality [3]. In addition, melatonin levels may be lower when cardiovascular disease is present [5]. Because of its metabolic effects, such as improved insulin resistance, antioxidant power and circadian rhythm control, more and more studies are examining the melatonin benefits for health $[5,6]$.

Thus, melatonin supplementation has been considered. Koziod et al., by a randomized trial in 33 healthy subjects showed that supplementation of melatonin $5 \mathrm{mg}$ for 2 months, improved lipid profile, antioxidant and blood pressure [7]. Two other studies observed, in addition to improvements in metabolic profile, improvements in insomnia levels and sleep quality with supplementation $10 \mathrm{mg} /$ day of melatonin $[8,9]$. In 33 patients with traumatic brain injury, supplementation of $2 \mathrm{mg}$ /day of melatonin for 4 weeks also showed objective and subjective improvements in sleep quality [10]. Despite the numerous benefits already described with supplementation, some small reports of adverse effects such as dizziness, nausea, drowsiness and headache in relation to placebos are observed. It 
is also noteworthy that further investigation of supplementation for population groups such as pregnant women, children, infants is still needed to obtain greater safety [11].

Regarding diet, it is possible to observe a positive correlation between the consumption of melatonin food sources and improvement of its circulation level. A study of healthy Japanese women evaluating the consumption of $350 \mathrm{~g}$ of vegetables for 65 days showed a significant increase of 6-sulfatoxymelatonin in the urine of these volunteers, indicating an improvement in circulating melatonin concentrations [12]. In turn, Nagata et al., using a frequency questionnaire of food intake, showed a positive association between the consumption of vegetables and urinary excretion of 6-sulfatoxymelatonin [13]. With respect to tropical fruits, it is possible to observe a considerable increase of 6-sulfatoxymelatonin in the urine with the consumption of pineapple, banana, and orange [14]. Animal studies assessing the intake of fermented goat milk and bean sprouts also show improvements in melatonin biomarker levels as well as antioxidant capacity $[15,16]$.

When it comes to melatonin in food, it stands out that it has already been detected and quantified in roots, buds, leaves, flowers, fruits and seeds. Higher concentrations can be found in plant reproductive organs, particularly seeds, which may be related to species survival through antioxidant defense [5]. Melatonin concentrations may also change within varieties of the same species, which may be related to the detection technique, extraction, as well as the environmental conditions that the specie variety was subjected to such as soil type, climate and solar incidence. The processing level of a food (cooking, fermentation, baking) can also influence melatonin concentrations, which shows the need to build consistent food composition tables for it $[5,6]$.

\section{Conclusion}

In this sense, it is observed that both in supplemental form and in diet, melatonin can have beneficial effects both in improving circadian rhythm, as well as in anti-inflammatory and metabolic processes. Despite this, the literature shows that there are still several gaps, especially when it comes to the benefit of dietary sources. Thus, further studies are needed to establish concrete and safe recommendations.

\section{References}

1. Zhao D, Yu Y, Shen Y, Liu Q, Zhao Z, et al. (2019) Melatonin Synthesis and Function: Evolutionary History in Animals and Plants. Front Endocrinol 10: 249 .
2. Souza, JA, Castro BF (2008) Melatonina, ritmos biológicos e sono-uma revisão da literatura. Revista brasileira de neurologia 44(1): 5-11.

3. Poza JJ, Pujol M, Ortega-Albás JJ, Romero O (2018) Melatonina enlostrastornos de sueño. Neurología.

4. Liu J, Clough SJ, Hutchinson AJ, Adamah-Biassi EB, Popovska-Gorevski M, et al. (2016) MT 1 and MT 2 Melatonin Receptors: A Therapeutic Perspective. Annu Rev Pharmacol Toxicol 56(1): 361-383.

5. Salehi B, Sharopov F, Fokou PVT, Kobylinska A, Jonge L, et al. (2019) Melatonin in Medicinal and Food Plants: Occurrence, Bioavailability, and Health Potential for Humans. Cells 8(7): 681.

6. Gomes Domingos AL, Hermsdorff HHM, Bressan J (2017) Melatonin intake and potential chronobiological effects on human health. Crit Rev Food Sci Nutr 59(1): 133-140.

7. Koziróg M, Poliwczak AR, Duchnowicz P, Koter-Michalak M, Sikora J, et al. (2011) Melatonin treatment improves blood pressure, lipid profile, and parameters of oxidative stress in patients with metabolic syndrome. J Pineal Res 50(3): 261-266.

8. El-Sharkawy H, Elmeadawy S, Elshinnawi U, Anees M (2019) Is dietary melatonin supplementation a viable adjunctive therapy for chronic periodontitis?-A randomized controlled clinical trial. J Periodontal Res 54(2): 190-197.

9. Shabani A, Foroozanfard F, Kavossian E, Aghadavod E, Ostadmohammadi $\mathrm{V}$, et al. (2019) Effects of melatonin administration on mental health parameters, metabolic and genetic profiles in women with polycystic ovary syndrome: A randomized, double-blind, placebo-controlled trial. J Affect Disord 250: 51-56.

10. Grima NA, Rajaratnam SMW, Mansfield D, Sletten TL, Spitz G, et al. (2016) Efficacy of melatonin for sleep disturbance following traumatic brain injury: a randomised controlled trial. BMC Med 16(1): 8.

11. Andersen LPH, Gögenur I, Rosenberg J, Reiter RJ (2016) The Safety of Melatonin in Humans. Clin Drug Investig 36(3): 169-175.

12. Oba S, Nakamura K, Sahashi Y, Hattori A, Nagata C (2008) Consumption of vegetables alters morning urinary 6-sulfatoxymelatonin concentration. J Pineal Res 45(1): 17-23.

13. Nagata C, Nagao Y, Shibuya C, Kashiki Y, Shimizu H (2005) Association of Vegetable Intake with Urinary 6-Sulfatoxymelatonin Level. Cancer Epidemiol Biomarkers Prev 14(5): 1333-1335.

14. Sae-Teaw M, Johns J, Johns NP, Subongkot S (2013) Serum melatonin levels and antioxidant capacities after consumption of pineapple, orange, or banana by healthy male volunteers. J Pineal Res 55(1): 5864.

15. Aguilera Y, Rebollo-Hernanz M, Herrera T, Cayuelas LT, RodríguezRodríguez P, et al. (2016) Intake of bean sprouts influences melatonin and antioxidant capacity biomarker levels in rats. Food Funct 7 (3): 1438-1445.

16. Moreno-Fernandez J, Diaz-Castro J, Alférez MJM, Nestares T, Ochoa JJ, et al. (2016) Fermented goat milk consumption improves melatonin levels and influences positively the antioxidant status during nutritional ferropenic anemia recovery. Food Funct 7(2): 834-842. 
(C) (i) $\begin{aligned} & \text { This work is licensed under Creative } \\ & \text { Commons Attribution 4.0 Licens }\end{aligned}$

BY DOI: 10.19080/JETR.2019.05.555651
Your next submission with Juniper Publishers will reach you the below assets

- Quality Editorial service

- Swift Peer Review

- Reprints availability

- E-prints Service

- Manuscript Podcast for convenient understanding

- Global attainment for your research

- Manuscript accessibility in different formats

( Pdf, E-pub, Full Text, Audio)

- Unceasing customer service

Track the below URL for one-step submission https://juniperpublishers.com/online-submission.php 